\section{РОЗВИТОК МІЖНАРОДНИХ ЕКОНОМІЧНИХ ВІДНОСИН В УМОВАХ ГЛОБАЛІЗАЦІї}

\author{
ТОМАШУК І.В. \\ доктор філософії з економіки, \\ асистент кафедри економіки та підприємницької \\ діяльності
}

ТОМЧУК О.Ф. кандидат економічних наук, доцент кафедри аналізу та статистики, Вінницький національний аграрний університет

(м. Вінниця)

ГИРЕНКО Ю.В. викладач, Відокремлений структурний підрозділ «Немирівський фаховий коледж будівництва, економіки та дизайну ВНАУ”

(м. Немирів)

У статті досліджено розвиток міжнародних економічних відносин в умовах глобалізації. Вказано, щуо однією із основних ознак сучасного розвитку світового господарства є розгортання прочесів глобалізачії, які справляють суттєвий вплив на систему міжнародних економічних відносин, трансформують напрями $i$ визначають тенденції розвитку наџіональних економік. Визначено, щзо глобалізацією світового господарства є прочес посилення взаємозв'язку національних економік країн світу, щзо знаходить своє вираження в утворенні світового ринку товарів $i$ послуг, фінансів; становленні глобального інформаційного простору, перетворенні знання в основний елемент суспільного багатства, виході бізнесу за національні кордони через формування транснаціональних корпорацій (далі - ТНК), впровадженні $і$ домінуванні в повсякденній практиці міжнародних відносин й внутрішньополітичного життя народів принщипово нових i універсальних ліберально-демократичних цінностей тощьо. Наголошено, щуо у сучасному світі глобалізація справляє домінуючий вплив на розвиток будь-якої держави. Акиентовано, щзо через розповсюдження інновацій у сфері технологій $і$ менеджменту, активний обмін товарами, послугами, інвестиціями глобалізація сприяє підвищенню ефективності функціонування національних економік, а з іншого - посилює нерівномірність, асинхронність та неспівмірність розвитку. Наголомено, щзо на макроекономічному рівні глобалізація проявлясться в прагненні держав та інтеграчійних об'єднань до економічної активності поза своїми кордонами за рахунок лібералізації торгівлі, зняття торгових й інвестиційних бар'єрів, створення зон вільної торгівлі тощуо. Крім того, процеси глобалізації та інтеграції охоплюють міждержавні узгоджені заходи щодо иілеспрямованого формування системи економічного, правового, інформачійно-комунікачійного, політичного простору у великих регіонах світу. Проаналізовано, щчо на сучасному етапі розвитку міжнародних відносин держави проводять як на світовому, так і на регіональному рівні активну спільну роботу 3 протистояння транснаціональним загрозам різного характеру (тероризму, екстремізму, організованій злочинності, наркобізнесу тощо); забезпечення продовольчої, енергетичної та екологічної безпеки; запобігання $і$ вирімення збройних конфліктів $і$ за багатьма іншими напрямами. Для досягнення успіху у иүій роботі державам можуть надати дієву допомогу 
різні міжнародні та регіональні організащії. Вказано, щзо важливу роль у розвитку економічних відносин відіграють логістичні системи. Інтенсивність галузевої взаємодії характеризують відносини мікрологістичної системи підприємства із зовнішнім середовищем макрологістичних зв'язків. Зроблено висновки, щзо всередині постіндустріального світу глобальні тенденції призводять, у кінцевому результаті, до зближення рівнів розвитку окремих країн $і$ їх жорсткого протистояння з рештою світу.

Ключові слова: глобалізація, інтеграція, економічне зростання, євроінтеграція, інтернаціоналізація, стратегія.

Табл.: 2. Рис.: 1. Літ.: 17.

\title{
DEVELOPMENT OF INTERNATIONAL ECONOMIC RELATIONS IN THE CONDITIONS OF GLOBALIZATION
}

\author{
TOMASHUK Inna \\ PhD of Economics,
} Assistant of the Department of Economics and Entrepreneurship

\begin{abstract}
TOMCHUK Olena
Candidate of Economic Sciences, Associate Professor of the Department of Analysis and Statistics, Vinnytsia National Agrarian University

(Vinnytsia)

GIRENKO Yulia

Teacher,

Separate Structural Subdivision «Nemyriv Professional College of Construction, Economics and Design VNAU»
\end{abstract}

(Nemyriv)

The article analyzes the development of international economic relations in the conditions of globalization. It is stated that one of the main features of modern development of the world economy are the deployment of globalization processes that have a significant impact on the system of international economic relations, transforming directions and determine the tendencies of development of national economies. It is determined that the globalization of the world economy is the process of strengthening the relationship between national economies of the world, which finds its expression in the formation of the world market of goods and services, finance; the formation of global information space, transformation of knowledge into the main element of social wealth, business outs for national borders through the formation of multinational corporations (hereinafter - TNCs), implementation and domestication in the daily practice of international relations and domestic life of peoples of fundamentally new and universal liberal-democratic values, etc. It is emphasized that in the modern world, globalization gives a dominant influence on the development of any state. It is accented that due to the dissemination of innovations in the field of technologies and management, the active exchange of goods, services, investments Globalization contributes to increasing the efficiency of the functioning of national economies, and on the other hand enhances unevenness, asynchronism and disproportionality of development. It is emphasized that globalization on the macroeconomic level manifests itself in the pursuit of states and integration associations to economic activity outside its borders due to the liberalization of trade, withdrawal of trade and investment barriers, creation of free trade zones, etc. In addition, the processes of globalization and integration include intergovernmental agreed measures for the purposeful 
formation of the system of economic, legal, informational, communication, political space in large regions of the world. It is analyzed that at the present stage of the development of international relations of the state, both on the world and regional level active joint work on confrontational threats of various character (terrorism, extremism, organized crime, drug trafficking, etc.) of provision, food, energy and environmental safety; preventing and solving armed conflicts and many other directions. In order to achieve success in this work, various international and regional organizations may be effective. It is indicated that logistics systems play an important role in the development of economic relations. The intensity of sectoral interaction characterizes the relationship of the micrologist system of the enterprise with an external medium of macrologistic ties. It is concluded that inside the post-industrial world, global tendencies leads to ultimately to convergence of levels of development of individual countries and their hard confrontation with the rest of the world.

Key words: globalization, integration, economic growth, eurointegration, internationalization, strategy.

Tabl.: 2. Fig.: 1. Lit.: 17.

\title{
РАЗВИТИЕ МЕЖДУНАРОДНЫХ ЭКОНОМИЧЕСКИХ ОТНОШЕНИЙ В УСЛОВИЯХ ГЛОБАЛИЗАЦИИ
}

\author{
ТОМАШУК И.В. \\ доктор философии с экономики, \\ ассистент кафедры экономики и предпринимательской деятельности
}

ТОМЧУК Е.Ф. кандидат экономических наук, доцент кафедры анализа и статистики, Винницкий национальный аграрный университет (2. Винница)

ГИРЕНКО Ю.В. преподаватель, Обособленное структурное подразделение «Немировский профессиональный колледжс строительства, экономики и дизайна ВНАУ,

(2. Немиров)

В статье исследовано развитие международных экономических отнотений в условиях глобализаџии. Указано, что одним из основных признаков современного развития мирового хозяйства является разширение прочессов глобализачии, которые оказывают существенное влияние на систему международных экономических отношений, трансформируют направления и определяют тенденции развития национальных экономик. Определено, что глобализацией мирового хозяйства является прочесс усиления взаимосвязи национальных экономик стран мира, что находит свое выражение в образовании мирового рынка товаров и услуг, финансов; становлении глобального информационного пространства, преобразовании знания в основной элемент общественного богатства, выходе бизнеса за национальные границь через формирование транснациональных корпораций (далее - ТНК), внедрении и доминировании в повседневной практике международных отношений и внутриполитической жизни народов принципиально новых $и$ универсальных либерально-демократических иенностей. Отмечено, что в современном мире 
глобализащия оказывает доминирующее влияние на развитие любого государства. Акцентировано, что из-за распространения инноваций в сфере технологий и менеджмента, активный обмен товарами, услугами, инвестициями глобализация способствует повышению эффективности функционирования национальных экономик, а с другой - усиливает неравномерность, асинхронность и диспропориию развития. Отмечено, что на макроэкономическом уровне глобализация проявляется в стремлении государств $u$ интеграционных объединений $\kappa$ экономической активности вне своих грании за счет либерализащии торговли, снятия торговых и инвестищионных барьеров, создании зон свободной торговли. Кроме того, прочессы глобализаџии и интеграции охватывают межгосударственные согласованные меры по целенаправленному формированию системы экономического, правового, информачионно-коммуникационного, политического пространства в крупных регионах мира. Проанализировано, что на современном этапе развития международных отношений государства проводят как на мировом, так и на региональном уровне активную совместную работу с противостояния транснациональным угрозам различного характера (терроризма, экстремизма, организованной преступности, наркобизнеса и m.n.) обеспечения продовольственной, энергетической и экологической безопасности; предотвращения и разрешения вооруженных конфликтов и многим другим направлениям. Для достижения успеха в этой работе государствам могут оказать действенную помощь различные международные и региональные организации. Указано, что важную роль в развитии экономических отношений играют логистические системы. Интенсивность отраслевого взаимодействия характеризуют отнотения микрологистической системы предприятия с внешней средой макрологистических связей. Сделаны выводы, что внутри постиндустриального мира глобальные тенденции приводят, в конечном итоге, к сближению уровней развития отдельных стран и их жесткого противостояния с остальным миром.

Ключевые слова: глобализация, интеграция, экономический рост, евроинтеграция, интернационализация, стратегия.

Табл.: 2. Рис.: 1. Лит.: 17.

Постановка проблеми. На сучасному етапі розвитку світової економіки відбуваються суттєві зміни всієї системи міжнародних відносин, посилюється взаємовплив та взаємозалежність різних сфер і чинників економіки, що $\epsilon$ закономірним і цілком логічним процесом. Поступове накопичення кількісних змін у розбудові світового господарства привели світ до якісно економічного зростання, до більш високої стадії інтеграції - глобалізації. Крім того, процеси глобалізації та інтеграції охоплюють міждержавні узгоджені заходи щодо цілеспрямованого формування системи економічного, правового, інформаційно-комунікаційного, політичного простору у великих регіонах світу. Особливої уваги на сучасному етапі розвитку економічних відносин потребує розгляд та дотримання концепції сталого розвитку.

Аналіз останніх досліджень і публікацій. Специфіку процесів глобалізації в умовах трансформаційного розвитку української економіки i проблем ефективної інтеграції України до світової економіки розглянуто у працях вітчизняних авторів Калетніка Г.М. [6], Гончарук I.В. [2], Заболотного Г.М. [6], Боярчука А.І. [1], Задорожнюк Н.О. [5], Куцика П.О. [7], Ковтуна О.І. [7], Башнянина Г.I. [7], Кокоріної В.I. [8], Радєвої М.М. [11], Мазур К.В. [9], Снігир Л.П. [12], Тарханової Н.О. [13], Харуна О.А. [14], Кошівської М.В. [14], Холода Б.I. [15], Зборовської О.М. [15], Циганова С.А. [16], Яншиної А.М. [16], Чернюка О.В. [17] та ін. 
Формулювання цілей статті. Метою статті є розгляд основних аспектів впливу процесів глобалізації на сучасні економічні системи світу та України, характеристика глобалізаційних чинників, які впливають на функціонування сучасної економічної системи України.

Виклад основного матеріалу дослідження. На сучасному етапі національна економіка переживає велику кризу. Виходом із такої важкої ситуації може бути лише найшвидший перехід до ринкової економіки разом із розширенням міжнародних економічних відносин. Україні потрібно більше розвивати свої міжнародні економічні відносини, тобто інтегруватися у світову економічну систему. У XXI столітті глобальні перетворення охоплюють усі сфери людського життя. Інтернаціоналізація продуктивних сил, вихід за національні кордони людського та фінансового капіталу, торгівля товарами та послугами, формування глобальних ринків роблять вирішальний вплив на політичні процеси, соціальну мобільність та міжкультурний діалог. Міжнародна економіка набуває ознак глобальної. Зростає роль національних економік як ключових гравців у світовому економічному полі.

Конкуруючи 3 транснаціональними корпораціями, як новими глобальними економічними суб'єктами, національні економіки інтегруються в могутні регіональні угрупування, а національні держави утворюють міждержавні та наддержавні організації та інститути.

В умовах економічної глобалізації «без кордонів» підвищується відповідальність національних держав за реалізацію ефективної економічної політики, яка б, з одного боку, забезпечувала реалізацію конкурентних переваг країни, використання позитивів глобалізації у національних інтересах, а 3 іншого, - запобігала їі негативам і «провалам» [6, с. 5; 10].

Сьогодні глобалізація виявляє свою складність і неоднозначність та має такі риси: поглиблення інтернаціоналізації капіталу - загальна лібералізація ринкових відносин і рух капіталу «будують» фундамент світової економіки (рис. 1).

На тлі глобалізації світової економіки Україна стикається з низкою суттєвих проблем, серед яких: сировинна орієнтація економіки, незначна інтеграція зі світовою економікою, нерозвиненість виробничої та соціальної інфраструктури, загальна технічна та технологічна відсталість підприємств, відсутність ефективного зв'язку науки 3 виробництвом, низькі витрати на дослідження та досвідчені проєктні роботи тощо. Для вирішення цих проблем Україна повинна розвивати інноваційну економіку, засновану на знаннях, нових інформаційних та технологічних інструментах, здатних стати основою суспільного добробуту.

Розвиток процесу глобалізації на сучасному етапі характеризується негативними тенденціями. Нещодавно Організацією економічного співробітництва та розвитку (далі - ОЕСР) наголошено на погіршенні темпів розвитку ВВП розвиненої економіки під впливом глобальної економічної кризи, що зайвий раз доводить думку Алана Грінспена, американського економіста, голови Ради керуючих Федеральної резервної системи США: «В умовах сьогодення започатковано рецесії таких масштабів, що не 
спостерігалися 3 1980-х років» [12, с. 35 ; 16, с. 11].

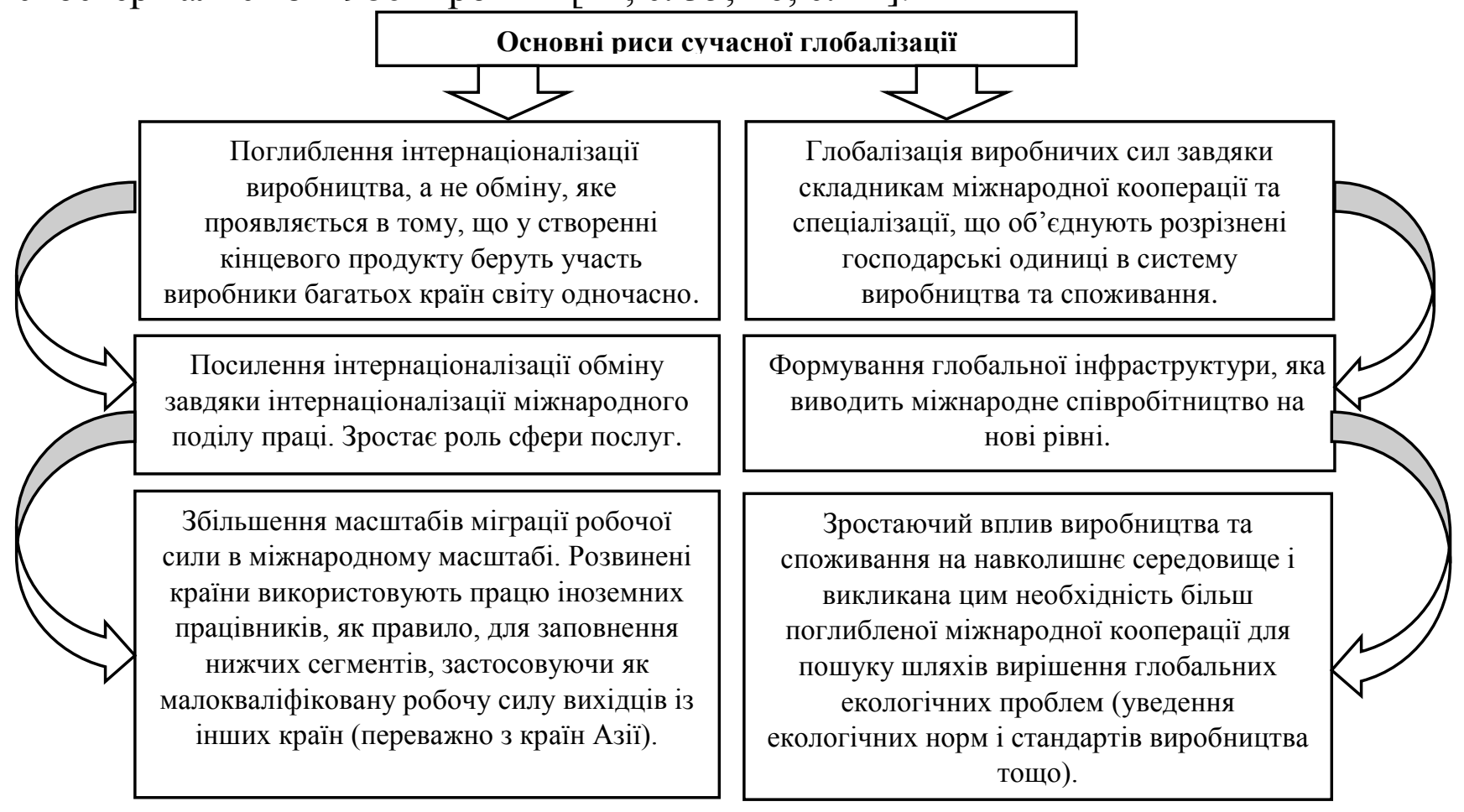

Рис. 1. Основні риси сучасної глобалізації

Джерело: сформовано авторами за результатами дослідження

В умовах глобалізації спостерігається зменшення ролі національної держави, втрата державної ідентичності, цілісності: на одному полюсі сучасної світової економіки зосереджуються країни - глобальні лідери 3 домінуванням США, на іншому полюсі світової економіки - більшість країн, для яких економічна глобалізація проявляється як якісно нові умови розвитку на які практично неможливо вплинути, але якої слід враховувати $[4 ; 7$, с. 38]. Особливо важливо враховувати масштаби та динаміку процесу становлення глобальної системи управління планетою та перерозподіл світового доходу, що не $є$ рівнозначним.

На макроекономічному рівні глобалізація проявляється у прагненні держав та інтеграційних об’єднань до економічної активності поза своїми кордонами за рахунок лібералізації торгівлі, зняття торгових й інвестиційних бар'єрів, створення зон вільної торгівлі тощо. Крім того, процеси глобалізації та інтеграції охоплюють міждержавні узгоджені заходи щодо цілеспрямованого формування системи економічного, правового, інформаційно-комунікаційного, політичного простору у великих регіонах світу.

Основним суб'єктом глобальних економічних процесів виступають багатонаціональні та глобальні транснаціональні корпорації, оскільки зовнішньоекономічна діяльність, у більшості випадків, для них має більш важливе значення, ніж внутрішні операції. Пріоритетним напрямком розвитку світових ТНК стає інноваційне інвестування, що забезпечує іх конкурентоспроможність i проникнення на міжнародні ринки, створення всередині ТНК необхідної інфраструктури, для розробки, просування i реалізації інноваційних проєктів [6, с. $7 ; 15$, с. 267]. На мікроекономічному рівні 
глобалізація проявляється в розширенні діяльності компаній за межі внутрішнього ринку, адже створення і розвиток ТНК дозволяє обійти існуючі бар’єри. Отже, можна стверджувати, що ТНК є основою процесу глобалізації, іiі головною рушійною силою.

Для України головним напрямом державної економічної політики в умовах глобалізації є розвиток внутрішнього ринку на підгрунті регіоналізації зовнішньої економічної діяльності. А це можливо за рахунок заморожування витрат виробництва на мінімальному рівні, зростання адресних соціальних програм (інструмент програми боротьби 3 бідністю і скороченням витрат), уведення паравалютної системи (долар/євро), підтримка пріоритетних галузей за принципом мультиплікатора [4; 16, с. 7]. Проте постає питання: яку найбільш сприятливу стратегію вибрати державі в умовах глобалізації?

На нашу думку, за несприятливого поєднання зовнішніх та внутрішніх умов і чинників розвитку економіки вітчизняної держави необхідно провести «форсовану» стратегію щодо переходу до інноваційної економіки. Передусім це вимагає радикальніших реформ у напрямі економіки, яка грунтується на інноваціях і знаннях, а саме - посиленні взаємозв'язку мережі «інтелектуальноінформаційна освіта - інноваційна наука - технологічне виробництво глобальний ринок - глобальна регіоналізація». За рахунок відкритості та взаємопосилення взаємозв'язку зазначеної мережі, постають глобальні інноваційно-технологічні ланцюжки вищого рангу (глобальні мережеві суб'єкти - університет, держава, регіон, бізнес) [1, с. 13; 10], які, в свою чергу, повинні мати гнучкі важелі інноваційної активності.

У цій стратегічній мережі посилюється роль закладів вищої освіти у взаємодії із промисловістю (бізнесом), самоврядуванням та урядом. Мегасуб'єкти «університет - держава - регіон - бізнес» прагнуть до кооперації $[1$, c. 13], де інноваційний складник генерується 3 цієї взаємодії, а не за ініціативою держави.

Особливої уваги на сучасному етапі розвитку економічних відносин потребує розгляд та дотримання концепції сталого розвитку. У процесі залучення ТНК до впровадження базових атрибутів сталого розвитку у країнах світу ключова роль належить ООН, яка, зокрема, формує нормативно-правові основи для гармонізації економічних, екологічних і соціальних інтересів. Серед найважливіших ініціатив ООН у цій сфері - Принципи відповідального інвестування, Глобальний договір і Фінансова ініціатива Програми ООН 3 навколишнього середовища, які об’єднують різних суб'єктів міжнародних економічних відносин у їх прагненні до сталого розвитку. Участь промислових підприємств і фінансових інститутів у реалізації ключових положень концепції сталого розвитку має відбуватися, насамперед, шляхом запровадження програм екологічно-безпечної організації праці; формування систем «екологічного контролю» у межах як фінансових, так і промислових ТНК для оцінки впливу підприємницької діяльності на навколишнє природне середовище (зокрема, через підвищення ефективності енергозбереження та водопостачання, зменшення обсягів витратних матеріалів та обов'язкової утилізації відходів); створення спеціалізованих фондів для фінансування дослідницьких програм, 
спрямованих на розв'язання проблем гармонізації економічних [1, с. $12 ; 17$, с. 147], екологічних і соціальних інтересів; сприяння сталому розвитку на міжнародному рівні.

Процеси економічної інтеграції відбуваються як на двосторонній, так і на регіональній або на глобальній основі. У сучасних умовах інтеграційні процеси носять регіональний характер і проявляються в регіонах із найрозвинутішою економікою та інтенсивним розвитком НТП: Західна Європа; Північна Америка; Південно-Східна Азія; Південна Америка. Головними учасниками i організаторами інтеграційного процесу виступають: держави; ТНК [4; 6, с. 10]; різні політичні партії та громадські організації; національні групи населення та окремі особи. Сучасними особливостями процесів міжнародної економічної інтеграції є динамічний розвиток, нерівномірність (за регіонами, рівнем розвитку), глобальний субрегіоналізм тощо.

У силу того, що сучасна світова економіка стає вкрай взаємозалежною, інтереси всіх іiі учасників вимагають активної співпраці в цілях підтримки стабільності не тільки в економічному, але й у військово-політичному плані. забезпечувати безпеку людини за допомогою політичних, дипломатичних та економічних заходів у процесі регулювання міжнародних відносин $[2$, с. $195 ; 11$, с. 11$]$.

Таким чином, сучасна система міжнародних відносин може існувати i розвиватися тільки в рамках ефективної системи міжнародної безпеки.

Глобалізація $є$ неможливою сама собою, тобто перераховані форми відносин $є$ необхідними умовами эі існування. Необхідними, проте не достатніми. Та нова якість глобалізованих світогосподарських зв'язків, яка виникла на початку XXI сторіччя, визначається новими передумовами (табл. 1).

Таблиия 1

Передумови нової якості глобалізованих світогосподарських зв'язків

\begin{tabular}{|c|c|c|}
\hline $\begin{array}{c}\text { № } \\
\Pi / \Pi\end{array}$ & Назва & Характеристика \\
\hline I & Технологічні & $\begin{array}{l}\text { Розвиток засобів зв'язку та інформації, який дозволяє проводити господарські } \\
\text { трансакції у різних точках земної кулі в режимі реального часу; } \\
\text { Зведення до мінімуму або до нуля часових лагів у процесі обороту капіталу, } \\
\text { пов'язаних із проведенням розрахунків (безготівкові розрахунки в сучасних } \\
\text { інформаційних банківських системах здійснюються миттєво); } \\
\text { Оформлення документів, яке базується на електронних записах інформаційного } \\
\text { обороту все більше витісняє «паперове») та пов'язане з цим прискорення оборотності } \\
\text { капіталу, залученого до світогосподарських зв’язків. }\end{array}$ \\
\hline II & Організаційні & $\begin{array}{l}\text { Величезні зрушення в інституційній структурі світового господарства, викликані: } \\
\text { суттєвим розширенням кордонів єдиного європейського простору; різкою зміною } \\
\text { структури країн світової торгівлі (суттєве підсилення позицій Китаю у світовій торгівлі } \\
\text { тощо). } \\
\text { Переділ світових ринків - факт, який здійснюється на очах, однак ще не є } \\
\text { завершеним. У ньому вже визначилися лідери та аутсайдери, але визначеності } \\
\text { остаточного результату немає. }\end{array}$ \\
\hline III & Культурні & $\begin{array}{l}\text { Планетарне розповсюдження стандартів матеріальної цивілізації європейського та } \\
\text { американського типів на рівні звичайної економічної свідомості - так звана культурна } \\
\text { експансія, рівно як й планетарне протистояння цій експансії (природньо, менш потужне } \\
\text { за засобами, але таке, що виступає незаперечним фактом). }\end{array}$ \\
\hline
\end{tabular}

Джерело: сформовано авторами за даними [2, с. 193; 11, с. 11] 
Важливо зазначити, що трансформація традиційної Вестфальської системи призвела до розширення кола суб'єктів міжнародних відносин: якщо раніше держави були домінуючими учасниками міжнародних відносин, то в останні роки на перший план виходять організації, окремі регіони, ТНК [3;8], міжнародні приватні фінансові інститути, неурядові громадські організації, які не мають певної національності. Також важливу роль у процесі розвитку міжнародних відносин відіграють різні міжнародні неурядові організації i фонди. Глобалізація міжнародних відносин також проявилася в успішному становленні та функціонуванні багатьох міжнародних інститутів, що вирішують найгостріші та невідкладні проблеми глобального масштабу: ООН і установи, що функціонують під ії егідою.

Таким чином, глобалізація як форма міжнародних економічних відносин - це процес інтернаціоналізації господарського життя на етапі формування інформаційного технологічного укладу в найбільш розвинутих країнах в умовах боротьби тенденцій формування однополюсного та багатополюсного (взамін попереднього двополюсного) політичного й економічного світового простору [3; 8].

Логістичні системи також відіграють важливу роль у розвитку економічних відносин. Інтенсивність галузевої взаємодії характеризується взаємозв'язком системи мікрологістики підприємства із зовнішнім середовищем макрологістики [3].

Так, сучасні міжнародні торгові відносини здійснюються за рахунок використання транспортно-логістичної інфраструктури, забезпечуючи перевезення товарів у інтермодальних і мультимодальних схемах. Найбільш значущі питання, які необхідно вирішити при побудові міжнародних логістичних систем, такі: створення вільного ринку перевезень без обмежень його місткості i навантаження; застосування тарифів, рекомендованих загальними регулюючими органами; лібералізація транспортних i митних процедур при перетинанні кордонів вантажами; узгодження перевізної здатності магістрального транспорту та продуктивності залізничних i складських пристроїв $[4 ; 12$, с. 34].

Сьогодні глобалізацією охоплені окремі сфери світової економіки, а саме: зовнішня, міжнародна, світова торгівля товарами, послугами, технологіями, об’єктами інтелектуальної власності; міжнародний рух чинників виробництва (робочої сили, капіталу, інформації); міжнародні фінансово-кредитні та валютні операції (безоплатне фінансування і допомога, кредити i позики суб'єктів міжнародних економічних відносин, операції із цінними паперами, спеціальні фінансові механізми та інструменти); виробнича, науково-технічна, технологічна сфера, інформаційне співробітництво.

На сучасному етапі розвитку міжнародних відносин держави ведуть активну спільну роботу як на глобальному, так і на регіональному рівнях для протистояння транснаціональним загрозам різного характеру (тероризм, екстремізм, організована злочинність, торгівля наркотиками тощо); забезпечення продовольчої, енергетичної та екологічної безпеки; запобігання та вирішення збройних конфліктів та багатьох інших сфер. Різні міжнародні та 
регіональні організації можуть надати дієву допомогу державам для досягнення успіху в цій роботі.

Глобалізація вплинула на широке використання логістичного підходу в становленні та подальшому розвитку міжнародних економічних, особливо, торгівельних відносин на світовому ринку. Саме глобалізація сприяє оптимізації розміщення ресурсів, розширенню асортименту товарів і підвищенню їх якості (табл. 2).

Таблиия 2

\section{Можливості й виклики глобальної економіки}

\begin{tabular}{|c|c|}
\hline & \\
\hline $\begin{array}{l}\text { потужної ресурсної бази й } \\
\text { ного потенціалу; } \\
\text { умов міжфірмової взаємодії та } \\
\text { тва; } \\
\text { ення можливостей до доткового } \\
\text { капіталів; }\end{array}$ & $\begin{array}{l}\text { ресурсу державного регулювання економічних процесів; } \\
\text { • деформації національного відтворювального процесу; } \\
\text { • поширення єдиних стандартів на національні культури; } \\
\text { • моральне старіння робочої сили; } \\
\text { • посилення дуалістичного характеру економіки; } \\
\text { • підвищення впливу зовнішніх факторів на розвиток } \\
\text { держави; } \\
\text { - отримання надприбутків за рахунок підприємств сусідніх } \\
\text { країн; } \\
\text { • монополізація застосування нових технологій та інформації; } \\
\text { - блокування ринків сировини та збуту; } \\
\text { • експансійна цінова політика; }\end{array}$ \\
\hline
\end{tabular}

\section{Джерело: сформовано авторами за результатами дослідження}

Сучасний рівень розвитку міжнародної економіки у контексті глобалізації характеризується як система науково-технологічних та галузевофункціональних зв'язків. Створення нових елементів продуктивних сил у вигляді інформаційно-комунікаційних технологій зумовило появу нових форм і методів міжнародного бізнесу, або їх модифікацію. Основою такого висновку є фундаментальне положення про взаємодію рівня продуктивних сил із характером виробничих відносин [8; 12, с. 33]. Нові елементи продуктивних сил у формі інформаційно-комунікаційних технологій мають вплив на економічні відносини, результатом чого стали більш сучасні, 3 точки зору технологій, форми міжнародного бізнесу, нові продукти, нові відносини продавця з покупцем, нові конкурентні та бізнес-стратегії.

Глобалізація як феномен XXI століття виявляється як багатовимірне явище, яке охоплює масштаби та динамізацію міжнародних економічних відносин i міжнародного бізнесу, й характеризує вищий рівень розвитку міжнародної економіки як системи науково-технологічних та галузевофункціональних зв'язків між новими типами утворень як кластерні, мегакорпораційні та мережеві структури, також зумовлює становлення глобальної економічної системи. Підкреслимо, що сьогодні рушійні сили економічної глобалізації формуються в умовах розвитку нового світоустрою 
[3;8], сформованого під впливом цивілізаційного розвитку продуктивних сил як результат домінування інформації та технології в економічній системі.

Україна має бути залучена до процесу регулювання глобальних проблем людства, оскільки світове співтовариство ввійшло в нову фазу розвитку - фазу становлення нової системи міжнародних відносин, яка змогла б дати відповіді, адекватні новим викликам сучасності. Успішне вирішення всіх глобальних питань людства у процесі глобалізації буде залежати від зусиль усіх жителів землі, від культури, освіченості й відповідальності кожного з нас.

Глобалізація ставить Україну перед проблемою самовизначення цілей розвитку і місця в сучасному світі - чи буде це експортно-сировинна модель розвитку, чи модель повноправного партнерства на світовій арені.

ТНК, як суб'єкти міжнародних ринкових відносин, відіграють важливу роль у цьому процесі; логістичні системи, що забезпечують ефективність взаємодії суб'єктів ринку та ключові аспекти концепції сталого розвитку, як теоретичні та практичні рекомендації щодо розвитку міжнародних економічних відносин в умовах глобалізації.

Процеси глобалізації сучасної світової економіки найтіснішим чином пов'язані з еволюцією їі інституціональної структури - інституціоналізацією світового господарства. Річ у тому, що в міжнародних економічних відносинах, так як і у рамках національних економічних систем окремих країн, формуються певні інститути (норми, ціннісні характеристики, «правила гри»), а також організації у вигляді зовнішньої формалізованої структури цих інститутів. У світогосподарських зв'язках складаються і видозмінюються конкретні соціальні інститути (що розуміються як синтез традиційних понять «інститут» i «організація»), відбувається інституціоналізація міжнародних економічних відносин.

До інститутів слід віднести так звані інфраструктурні складові міжнародних торгових відносин - банки, товарні біржі, міжнародні багатосторонні товарні угоди, покликані регулювати окремий сегмент світового ринку, і відповідні ним організації («класичний» випадок такої організації фактичний картель країн-виробників нафти ОПЕК), двосторонні торгові угоди, ЮНКТАД (Конференція ООН 3 торгівлі і розвитку) та інші пов'язані 3 міжнародною торгівлею організації ООН. Окремо слід згадати регіональні інтеграційні організації (ЄС, НАФТА, МЕРКОСУР і багато ін.) і діючий у їх рамках механізм регулювання взаємної торгівлі $[9$, с. $72 ; 16$, с. 11]. У той же час ведучою міжнародною регулюючою організацією, діючою у сфері міжнародної торгівлі, є СОТ.

Для успішної інтеграції України в глобалізаційне поле світового господарства необхідна довгострокова зовнішньоекономічна стратегія. У сфері зовнішньоекономічної політики до теперішнього часу втрачена і не відновлена необхідна комплексність і системність у діяльності відповідних державних органів країни [3; 17, с. 149]. В умовах наростання в країні фінансовоекономічної кризи, загострення соціально-економічних проблем і намагань зі сторони центру вирішувати їх на селективній, вибірній основі цілком 
можливим стає посилення протиріч між центром й регіонами і навіть посилення сепаратистських тенденцій.

Українська стратегія глобалізації не повинна бути однобокою, що зачіпає лише одну сферу - економіку, торгівлю, фінанси; вона повинна бути комплексною. Нова глобалізаційна стратегія розвитку повинна будуватися на науково-обгрунтованій національній стратегії розвитку, що враховує загальносвітові проблеми.

Стратегія адаптації України до глобалізаційних процесів включає взаємопов’язані стратегіï, що реалізуються державою залежно від ступеня інтенсивності впливу факторів глобалізації на національну економіку [4; 9, c. 75]. Зокрема, в Україні доцільно впровадити стратегію стимулювання глобалізаційних процесів. На першому етапі стратегія повинна базуватися на підтримці існуючих досягнень: вирішенні спільних зусиль глобальних проблем; допомога найменш розвиненим країнам та регіонам; активна участь у діяльності міжнародних організацій.

На другому етапі зовнішньоекономічна стратегія стимулювання процесу

.
глобалізації повинна передбачати: активну інтеграцію; зміцнення валюти країни; налагодження експортно-імпортних зв'язків, збільшення товарообігу; поєднання експортно-орієнтованої економіки 3 власним конкурентоспроможним виробництвом; вдосконалення законодавства та інвестиційного клімату; поліпшення рівня життя населення; спрямування інвестицій на розвиток інфраструктури; участь у діяльності міжнародних організацій, налагодження інтеграційних зв'язків; участь у побудові нової фінансової архітектури та інші заходи [11, с. 9; 17, с. 147].

Україна повинна побудувати якісно нову соціально-орієнтовану модель глобалізації, основою якої повинна стати особистість, а метою держави перехід від індустріального до інформаційного етапу розвитку. Основними принципами, здатними об'єднати населення України, є забезпечення рівних стартових умов на інноваційному рівні; гарантовані соціальні стандарти для всіх верств населення.

Висновки. Отже, в умовах глобалізації формується якісно нова система міжнародних відносин, заснована на принципово новому рівні взаємодії країн.

Основним суб'єктом глобальних економічних процесів виступають багатонаціональні та глобальні ТНК. Тому, можна стверджувати, що ТНК $\epsilon$ основою процесу глобалізації, іiі головною рушійною силою. Крім того, глобалізація міжнародних відносин проявилася в успішному становленні та функціонуванні багатьох міжнародних інститутів, що вирішують найактуальніші проблеми світового масштабу: ООН i установи, що функціонують під ії егідою.

Для успішної інтеграції України у сферу глобалізації світової економіки потрібна довгострокова комплексна зовнішньоекономічна стратегія.

\section{Список використаних джерел}

1. Боярчук А.І. Глобальна регіоналізація як мегатренд фрагментації світового господарства. Причорноморські економічні студї. 2018. № 27. 
C. 11-14.

2. Гончарук I.В. Розвиток інвестиційного середовища та інвестиційного процесу. Науковий вісник НЛТУ України. 2011. № 21. Вип. 8. С. 192-198.

3. Глобалізація міжнародних економічних відносин: сутність та особливості ну сучасному етапі. URL: https://pidru4niki.com/84642/ekonomika/globalizatsiya_mizhnarodnih_ekonomichni h_vidnosin_sutnist_osoblivosti_suchasnomu_etapi (дата звернення: 20.03.2021).

4. Економічна теорія. URL: https://osvita.ua/vnz/reports/econom_theory (дата звернення: 17.03.2021).

5. Задорожнюк Н.О. Розвиток міжнародних економічних відносин в умовах глобалізації. URL: https://conf.ztu.edu.ua/wpcontent/uploads/2017/01/360.pdf (дата звернення: 14.02.2021).

6. Калетнік Г.М., Заболотний Г.М., Козловський С.В. Інноваційні моделі управління стратегічним економічним потенціалом сучасних економічних систем. Актуальні проблеми економіки. 2011. № 4. С. 3-11.

7. Куцик П., Ковтун О., Башнянин Г. Глобальна економіка: принципи становлення, функціонування, регулювання та розвитку: монографія. Львів: Видавництво ЛНК. 2015. 594 с.

8. Кокоріна В.І. Основні тенденції розвитку форм міжнародного бізнесу в умовах глобалізації. Ефективна економіка. 2012. № 6. URL: http://www.economy.nayka.com.ua/?op=1\&z=120 (дата звернення: 11.03.2021).

9. Mazur K.V., Tomashuk I.V. Governance and regulation as an indispensable condition for developing the potential of rural areas. Baltic Journal of Economic Studies. 2019. Vol. 5. № 5. P. 67-78.

10. Міжнародна економіка. URL: https://kart.edu.ua/wpcontent/uploads/2020/07/mizhnarodna-ekonomika-3.pdf (дата звернення: 03.03.2021).

11. Радєва М.М. Україна в глобальній економіці: виклики і можливості. Економіка та держава. 2012. № 3. С. 8-11.

12. Снігир Л.П. Проблеми та перспективи глобалізації міжнародних економічних відносин. Інфраструктура ринку. 2018. № 22. С. 33-36.

13. Тарханова Н.О. Глобалізація світового господарства та їі вплив на економічний розвиток України. Вісник Донбаської національної академії будівництва і архітектури. 2013. № 2 (100). С. 98-103.

14. Харун О.А., Кошівська М.В. Економічна глобалізація як інструмент вирішення глобальних проблем людства. Східна Європа: економіка, бізнес та управління. 2017. № 6 (11). С. 25-29.

15. Холод Б.I., Зборовська О.М. Глобалізація як фактор впливу на процеси логістичного управління зовнішньоекономічною діяльністю підприємств. Свропейський вектор економічного розвитку. 2014. № 2 (17). С. 261-270.

16. Циганов С.А., Яншина А.М. Проблеми сталого розвитку у контексті неоліберальної моделі глобалізації. Економіка України. 2013. № 4. С. 4-14.

17. Чернюк О.В. Основні тенденції сучасних процесів глобалізації. Актуальні проблеми міжнародних відносин. 2012. № 110. (Ч. I). С. 142-150. 


\section{References}

1. Boiarchuk, A.I. (2018). Hlobalna rehionalizatsiia yak mehatrend frahmentatsii svitovoho hospodarstva [Global Regionalization as Megatrand Fragmentation of the World Economy]. Prychornomorski ekonomichni studii-Black Sea Economic Studies, 27, 11-14 [in Ukrainian].

2. Honcharuk, I.V. (2011). Rozvytok investytsiinoho seredovyshcha ta investytsiinoho protsesu [Development of investment environment and investment process]. Naukovyi visnyk NLTU Ukrainy - Scientific Bulletin of the NLTU of Ukraine, 21, 8, 192-198 [in Ukrainian].

3. Hlobalizatsiia mizhnarodnykh ekonomichnykh vidnosyn: sutnist ta osoblyvosti na suchasnomu etapi [Globalization of International Economic Relations: Essence and Features at the Modern Stage]. pidru4niki.com. Retrieved from: https://pidru4niki.com/84642/ekonomika/globalizatsiya_mizhnarodnih_ekonomichni h_vidnosin_sutnist_osoblivosti_suchasnomu_etapi [in Ukrainian].

4. Ekonomichna teoriia [Economic theory]. osvita.ua. Retrieved from: https://osvita.ua/vnz/reports/econom_theory [in Ukrainian].

5. Zadorozhniuk, N.O. Rozvytok mizhnarodnykh ekonomichnykh vidnosyn v umovakh hlobalizatsii [Development of international economic relations in the conditions of globalization]. conf.ztu.edu. Retrieved from: https://conf.ztu.edu.ua/wpcontent/uploads/2017/01/360.pdf [in Ukrainian].

6. Kaletnik, H.M., Zabolotnyi, H.M., \& Kozlovskyi, S.V. (2011). Innovatsiini modeli upravlinnia stratehichnym ekonomichnym potentsialom suchasnykh ekonomichnykh system [Innovative Models of Management of Strategic Economic Potential of Modern Economic Systems]. Aktualni problemy ekonomiky - Actual problems of the economy, 4, 3-11 [in Ukrainian].

7. Kutsyk, P., Kovtun, O., \& Bashnianyn, H. (2015). Hlobalna ekonomika: pryntsypy stanovlennia, funktsionuvannia, rehuliuvannia ta rozvytku [Global Economics: Principles of Formation, Functioning, Regulation and Development]. Lviv: Vydavnytstvo LNK [in Ukrainian].

8. Kokorina, V.I. (2012). Osnovni tendentsii rozvytku form mizhnarodnoho biznesu $\mathrm{v}$ umovakh hlobalizatsii [The main trends in the development of international business forms in the conditions of globalization]. Efektyvna ekonomika - Effective economy, 6. Retrieved from: http://www.economy.nayka.com.ua/?op=1\&z=120 [in Ukrainian].

9. Mazur, K.V., \& Tomashuk, I.V. (2019). Governance and regulation as an indispensable condition for developing the potential of rural areas. Baltic Journal of Economic Studies, 5, 5, 67-78 [in English].

10. Mizhnarodna ekonomika [International Economics]. kart.edu.ua. Retrieved from: https://kart.edu.ua/wp-content/uploads/2020/07/mizhnarodna-ekonomika-3.pdf [in Ukrainian].

11. Radieva, M.M. (2012). Ukraina v hlobalnii ekonomitsi: vyklyky i mozhlyvosti [Ukraine in the global economy: challenges and opportunities]. Ekonomika ta derzhava - Economy and State, 3, 8-11 [in Ukrainian].

12. Snihyr, L.P. (2018). Problemy ta perspektyvy hlobalizatsii mizhnarodnykh ekonomichnykh vidnosyn [Problems and prospects of globalization of international 
economic relations]. Infrastruktura rynku - Market infrastructure, 22, 33-36 [in Ukrainian].

13. Tarkhanova, N.O. (2013). Hlobalizatsiia svitovoho hospodarstva ta yii vplyv na ekonomichnyi rozvytok Ukrainy [Globalization of the world economy and its influence on Ukraine's economic development]. Visnyk Donbaskoi natsionalnoi akademii budivnytstva $i$ arkhitektury - Bulletin of the Donbas National Academy of Construction and Architecture, 2(100), 98-103 [in Ukrainian].

14. Kharun, O.A., \& Koshivska, M.V. (2017). Ekonomichna hlobalizatsiia yak instrument vyrishennia hlobalnykh problem liudstva [Economic globalization as a tool for solving global problems of mankind]. Skhidna Yevropa: ekonomika, biznes ta upravlinnia - Eastern Europe: Economics, Business and Management, 6 (11), 25-29 [in Ukrainian].

15. Kholod, B.I., \& Zborovska, O.M. (2014). Hlobalizatsiia yak faktor vplyvu na protsesy lohistychnoho upravlinnia zovnishnoekonomichnoiu diialnistiu pidpryiemstv [Globalization as a factor of influence on the processes of logistics management of foreign economic activity of enterprises]. Yevropeiskyi vektor ekonomichnoho rozvytku - European Vector Economic Development, 2 (17), 261-270 [in Ukrainian].

16. Tsyhanov, S.A., \& Yanshyna, A.M. (2013). Problemy staloho rozvytku u konteksti neoliberalnoi modeli hlobalizatsii [Problems of sustainable development in the context of the neoliberal model of globalization]. Ekonomika Ukrainy - Ukraine economy, 4, 4-14 [in Ukrainian].

17. Cherniuk, O.V. (2012). Osnovni tendentsii suchasnykh protsesiv hlobalizatsii [The main trends of modern globalization processes]. Aktualni problemy mizhnarodnykh vidnosyn - Actual problems of international relations, 110, I, 142150 [in Ukrainian].

\section{Відомості про авторів}

ТОМАШУК Інна Вікторівна - доктор філософії з економіки, асистент кафедри економіки та підприємницької діяльності, Вінницький національний аграрний університет (21008, м. Вінниця, вул. Сонячна, 3, e-mail: tomashuk.inna@ukr.net).

ТОМЧУК Олена Феліксівна - кандидат економічних наук, доцент кафедри аналізу та статистики, Вінницький національний аграрний університет (21008, м. Вінниця, вул. Сонячна, 3, e-mail: olenatomchuk@ukr.net).

ГИРЕНКО Юлія Василівна - викладач, Відокремлений структурний підрозділ «Немирівський фаховий коледж будівництва, економіки та дизайну ВНАУ» (22800, м. Немирів, вул. Гімназійна, 29, e-mail: ugirenko1983@gmail.com).

TOMASHUK Inna - PhD of Economics, Assistant of the Department of Economics and Entrepreneurship, Vinnytsia National Agrarian University (21008, Vinnytsia, 3, Soniachna Str., e-mail: tomashuk.inna@ukr.net).

TOMCHUK Olena - Candidate of Economic Sciences, Associate Professor of the Analysis and Statistics Department, Vinnytsia National Agrarian University (21008, Vinnytsia, 3, Soniachna str., e-mail: olenatomchuk@ukr.net). 
GIRENKO Yulia - Teacher, Separate Structural Subdivision «Nemyriv Professional College of Construction, Economics and Design VNAU» (22800, Nemyrov, 29, Gymnasium Str., e-mail: ugirenko1983@gmail.com).

ТОМАШУК Инна Викторовна - доктор философии с экономики, ассистент кафедры экономики и предпринимательской деятельности, Винницкий национальный аграрный университет (21008, г. Винница, ул. Солнечная, 3, e-mail: tomashuk.inna@ukr.net).

ТОМЧУК Елена Феликсовна - кандидат экономических наук, доцент, доцент кафедры анализа и статистики, Винницкий национальный аграрный университет (21008, г. Винница, ул. Солнечная, 3, e-mail: olenatomchuk@ukr.net).

ГИРЕНКО Юлия Васильевна - преподаватель, Обособленное структурное подразделение «Немировский профессиональный колледж строительства, экономики и дизайна ВНАУ» (22800, г. Немиров, ул. Гимназическая, 29, e-mail: ugirenko1983@gmail.com).

УДК 657:631.147

DOI: 10.37128/2411-4413-2021-2-15

\author{
ЗАКОНОДАВЧЕ \\ РЕГУЛЮВАННЯ \\ ОБЛІКУ \\ ОРГАНІЧНОГО \\ ВИРОБНИЦТВА В \\ УКРАÏHI
}

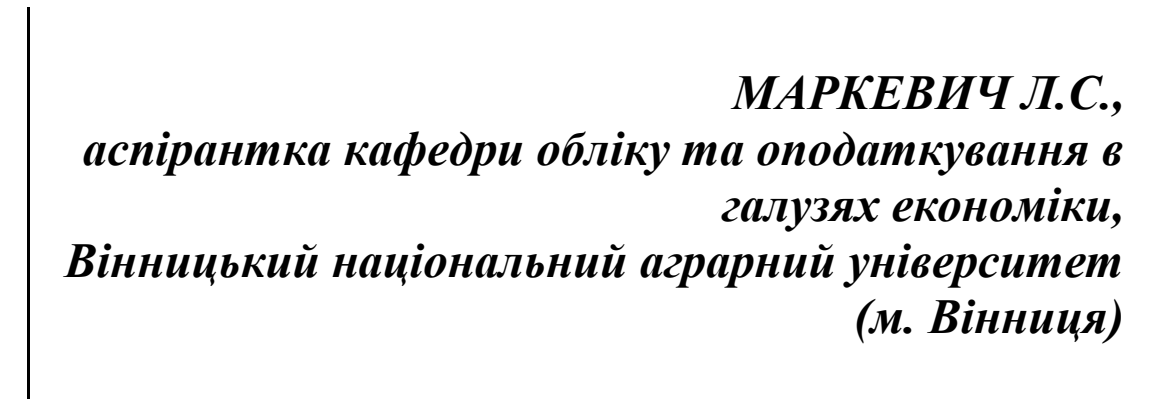

У статті проведено дослідження думок науковизів із актуальних питань обліку виробництвва органічної продукиії. Розкрито сучасний стан світового споживчого ринку екопродуктів, зазначено активне зростання попиту споживачів щуодо органічних продуктів. Досліджено правове регулювання органічного виробництва та розкрито різні погляди вчених щуодо напрямів удосконалення діючого законодавства в Украӥні. Представлено на законодавчому рівні закріплення змісту так званої «органіки». Виокремлено організацію ведення первинного обліку господарських операцій, пов'язаних із органічним землеробством на вітчизняних сільськогосподарських підприємствах. Розглянуто необхідність розробки типових форм документів та Методичних рекомендацій щуодо організації ведення обліку в умовах органічного виробництва в Україні. 3'ясовано основні галузі органічного виробництва в Україні. Представлено особливості та визначено недоліки формування облікової політики на «органічних підприємствах». Розглянуто перелік типової документації «органічних підприємств» із обліку виробництва органічної продукції рослинництва. Встановлено недосконалість нормативно-правової бази та відсутність належного інформаційного забезпечення, а також їх вплив на роботу «органічних підприємств». Підтверджено необхідність здійснення відображення у показниках фінансової звітності облікових даних про витрати на органічне виробництво та наявність і рух органічної сільськогосподарської продукиіі. За результатами дослідження визначено необхідність розробки методологічного інструментарію для обліку органічного виробництва. 3 розвитком органічного виробництва має бути належним чином організована система обліку, яка сприятиме забезпеченню користувачів своєчасною та достовірною інформацією про виробництво, зберігання та 